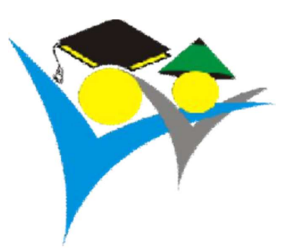

\title{
Transfer Teknologi Peningkatan Produktivitas pada Lahan Terbatas di Kecamatan Kayangan, Kabupaten Lombok Utara
}

\author{
Nurrachman $^{1 *}$, Jayaputra $^{1}$, Bambang Budi Santoso ${ }^{1}$

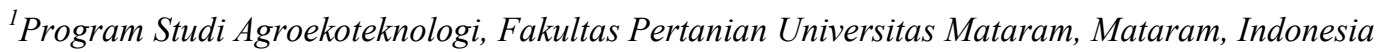

\section{Article history}

Received: 4 Juli 2021

Revised: 5 Juli 2021

Accepted: 6 Juli 2021

*Corresponding Author:

Nurrachman,

Program Studi

Agroekoteknologi, Fakultas

Pertanian Universitas Mataram, Mataram, Indonesia;

Email:

nurrachman.deden@unram.ac.id

\begin{abstract}
The development of tourism in North Lombok Regency is quite high, but since 2019 until now tourism has decreased due to the earthquake and the COVID-19 pandemic, as a result horticultural farmer have been affected by the decreasing tourism. To increase the income of farmers, especially limited land, horticultural products must be selected, such as fast in harvesting, input efficiency and increase land productivity. Sweet corn, especially baby corn and lettuce, still has a good market. Technology transfer of increasing land productivity is needed to overcome this problem by intercropping sweet corn with lettuce. Counseling and demonstration plots using participatory applied. The demonstration plots were carried out from July to August 2020 in the Sub-in Kekait Village, Kayangan Subdistrict, North Lombok. The demonstration plot results show satisfactory results with a land equivalence value (LER) of 1.62, meaning an increase of about 0.62 compared to corn or lettuce monocultures. This means that the farmers applied the technology will receive more product and income.
\end{abstract}

Keywords: sweetcorn; lettuce; productivity; intercropping

Abstrak: Perkembangan pariwisata di Kabupaten Lombok Utara cukup tinggi, namun sejak tahun 2019 hingga saat ini pariwisata mengalami penurunan akibat gempa dan pandemi COVID-19, akibatnya para petani hortikultura terkena imbas dari penurunan pariwisata tersebut. Untuk meningkatkan pendapatan petani, terutama lahan yang terbatas, produk hortikultura harus dipilih, seperti cepat dalam panen, efisiensi input dan peningkatan produktivitas lahan. Jagung manis khususnya baby corn dan selada masih memiliki pasar yang baik (Ifsca, 2020). Transfer teknologi peningkatan produktivitas lahan diperlukan untuk mengatasi masalah ini dengan melakukan tumpangsari jagung manis dengan selada. Penyuluhan dan demplot menggunakan partisipatif diterapkan. Demplot dilakukan pada bulan Juli -Agustus hingga 2020 di Kelompok Tani Tangkok Kliang Desa Sesait , Kayangan, Lombok Utara. Hasil demplot menunjukkan hasil yang memuaskan dengan nilai nilai kesetaraan lahan (LER) sebesar 1,62, artinya meningkat sekitar 0,62., dibandingkan dengan monokultur jagung atau selada. Artinya, petani yang menerapkan teknologi tersebut akan mendapatkan produk dan pendapatan yang lebih banyak.

Kata kunci: jagung manis; selada; produktifitas; tumpangsari

\section{PENDAHULUAN}

Kepemilikan lahan pertanian di Kabupaten Lombok Utara, semakin lama semakin sempit, peningkatan produksi atau produktivitas lahan harus dilakukan untuk memperoleh pendapatan yang cukup bagi keluarga. Petani hortikultura sampai saat ini hanya melakukan budidayanya secara monokultur, cenderung mengikuti pola tanam yang ada di desanya. Akibatnya, bila panennya bersamaan maka harga produk rendah, dan bila ada serangan penggangu tanaman maka akan terjadi kegagalan panen. (Nurrachman, 2015., Nurrachman dkk., 2019), mengemukakan bahwa penerapan teknologi budidaya salah satunya dengan menanam dua atau lebih tanaman atau di lahan pertanian akan dapat menekan kegagalan tersebut di atas. Pemilihan tanaman juga menjadi salah satu acuan untuk digunakan dalam sistem ini. Pemilihan tanaman yang mempunyai harga yang relatif stabil, dan waktu panen yang singkat, menjadi pilihan utama dalam sistem tumpangsari. Jagung manis, dan selada merupakan tanaman yang mempunyai harga relatif stabil dibandingkan dengan tanaman lain (IFSCA, 2020), permintaan pasar 
lokal di Kabupaten Lombok Utara cukup besar, sehingga tanaman ini menjadi pilihan utama untuk pola tumpangsari. Pemilihan tanaman dalam sistem tumpangsari berdasarkan pada perbedaan sifat tanaman, sehingga kompetisi yang terjadi dapat ditekan, selain itu pemilihan tanaman perlu diperhatikan terutama pada perbedaan karakter, morfologi, dan fisiologi seperti kedalaman dan distribusi perakaran, bentuk tajuk, laju fotosintesis, dan pola serapan unsur hara, serta pola pertumbuhan tanaman, karena berhubungan dengan pertumbuhan vegetatif dan generatif. Jagung manis dipanen pada umur 70 hari sedang kan Selada 35 hari, sehingga ada perbedaan pola pertumbuhan dan kemungkinan sedikit persaingan faktor produksi. Sistem tumpangsari dapat mengoptimalkan penggunaan hara, air dan sinar matahari sehingga meningkatkan produktivitas lahan dan hasil tanaman (Nawawi, 2013), dengan demikian dapat diperoleh produktivitas lahan yang tinggi (Herlina, 2014). Lebih lanjut Herlina (2014), menyatakan bahwa kompetisi saat pertumbuhan vegetative mempengaruhi pertumbuhan dan hasil; tanaman. Tumpangsari jagung manis dan brokoli dilaporkan memberikan hasil terbaik diperoleh pada waktu tanam yang bersamaan (Nurrachman, dkk., 2019a).

Waktu tanam berhubungan dengan pertumbuhan vegetatif adalah penundaan waktu tanam satu jenis tanaman yang ditumpangsarikan bertujuan agar pertumbuhan maksimum terjadi pada waktu yang tidak bersamaan. Hal ini akan membantu usaha pencapaian potensi produksi dari kedua jenis tanaman yang ditumpangsarikan.

Jagung manis biasanya ditanam dengan jarak tanam 20x70 cm. Jarak tanam yang cukup longgar mengakibatkan cahaya yang diteruskan/diserap daun jagung cukup besar, hal ini dapat dimanfaatkan untuk pertumbuhan tanaman lain di bawah naungan jagung. Pemanfaatan ruang di antara tanaman jagung dapat meningkatkan produktivitas lahan. Salah satu tanaman yang secara ekologis dan ekonomi memberikan keuntungan adalah Selada. Selada akan tumbuh baik dengan naungan karena membutuhkan temperatur kurang dari $25^{\circ} \mathrm{C}$, hampr sama dengan tanaman yang sejenis seperti brokoli dan kol bunga (Nurrachman dkk., 2019b). Di samping itu, selada mempunyai perakaran dangkal dan penyebarannya tidak luas. Jika Selada dipakai untuk tanaman sela kemungkinan besar tidak berkompetisi dengan tanaman utamanya yaitu jagung manis.

Berdasarkan uraian di atas, telah dilakukan kegiatan pengabdian kepada masyarakat sebagai upaya peningkatan pengetahuan terutama dalam mengusahakan tanaman hortikultura secara tumpangsari antara jagung manis dan selada yang dilakukan di kelompok tani Tani Tangkok Kliang, Desa Sesait Kecamatan Kayangan. Program dilaksanakan dari bulan Juli-September 2020 bekerjasama dengan IFSCA Program. Tujuan program adalah memberikan pelatihan tentang cara pengelolaan lahan pertanian dengan materi utama pelatihan adalah budidaya jagung manis dan selada dengan menerapkan teknologi tumpangsari dengan tujuan untuk meningkatkan produktivitas lahan.

\section{METODE}

\section{Lokasi dan Waktu Pelaksanaan}

Lokasi Pengembangan Kawasan Hortikultura di Kabupaten Lombok Utara, diarahkan pada daerah-daerah yang telah disurvey pada waktu penyusunan rencana kegiatan kerjasama Unram-Massey dengan Kabupaten Lombok Utara tahun 2017-2019, yaitu di Kecamatan Kayangan Desa Kekait, Kelompok Tani Tangkok Kliang. Kegiatan program aksi kegiatan (demplot), pendampingan petani, dan evaluasi hasil kegiatan. Pada tahun 2019, dilakukan juga kegiatan demplot tumpang sari jagung manis dengan brokoli dan berhasil cukup baik (Nurrachman, dkk., 2019a), sehingga dilakukan lagi dengan mengganti tanaman sela dengan selada karena permintaan produk ini cukup tinggi sejalan dengan menggeliatnya kembali sektor pariwisata.

Kondisi Desa Sesait yang terletak di dataran rendah dicirikan dengan suhu harian yang cukup tinggi yaitu sekitar $30^{\circ} \mathrm{C}$, dengan curah hujan yang rendah, sehingga untuk mengatasi curah hujan rendah diterapkan pembuatan penampung air irigasi dengan menggunakan terpal. Penanaman Brokoli di daerah ini jarang dilakukan oleh petani karena pengetahuan yang terbatas, dan beranggapan bahwa brokoli hanya dapat tumbuh baik di dataran tinggi. Oleh karena itu, dalam denplot ini diterapkan sistem atau cara pemupukan tumpangsari dengan jagung yang diharapkan dapat menutrunkan temperatur sekitar tanaman brokoli. Disamping itu, tumpang sari dengan tanaman yang mempunyai nilai ekonomi tinggi seperti jagung manis dapat memberikan keuntungan ekonomi. Pola tumpangsari dan cara pengelolaan tanaman yang lebih praktis dapat merangsang petani untuk melakukan cara tersebut. Dengan teknologi tersebut diharapakan produktivitas lahan dapat meningkat. 


\section{Metode Penyuluhan}

Penyusunan program aksi dilakukan melalui pertemuan sumbang saran (partisipatif) yang difasilitasi oleh Tim guna menghasilkan kegiatan yang berdampak pada peningkatan pendapatan petani dan kesiapan sumberdaya terutama keterampilan petani setempat. Masyarakat dilibatkan tidak hanya petani tetapi juga petani yang berperan ganda sebagai pelaku usaha di pasar local Santong. Hasil diskusi merumuskan bahwa jagung manis masih banyak dibutuhkan sehingga pasokan pasar masih kurang. Selada dipakai sebagai tanaman sela untuk memenuhi pasar Gili dan rumah makan yang ada Lombok Utara. Dengan cara seperti ini, maka diharapkan bahwa program aksi yang tersusun nanti adalah program yang sesuai dengan kebutuhan masyarakat.

\section{Penyuluhan}

Penyuluhan dilakukan dengan presentasi menggunakan Power Point dan diikuti diskusi/ tanya jawab. Presentasi Power Point bertujuan untuk memperkuat ceramah dengan contoh-contoh teknik pengelolaan secara visual. Diskusi dilakukan untuk memberikan pemahaman pengelolaan lahan hortikultura, keberlanjutan produksi, pendapatan dan keamanan lingkungan. Prinsip pengelolaan budidaya tanaman hortikultura adalah dengan menerapkan "Growsafe" artinya aman untuk konsumen dan lingkungan. Diskusi Penguatan pengetahuan petani tentang masalah dalam tumpangsari, kualitas dan target pasar, tidak hanya dilakukan oleh tim, tetapi juga melibatkan PPL setempat, aparat desa. Pertanyaan banyak dikemukakan oleh petani terutama masalah kebutuhan hotel, mengenai jenis dan harga yang ditawarkan. Selain itu bagaimana cara untuk memproduksi secara terus menerus untuk mensuplai kebutuhan hotel tersebut.

\section{HASIL DAN PEMBAHASAN}

Secara umum diperoleh gambaran bahwa petani sudah mengetahui dan menjalanjan bagaimana cara pengolahan lahan dengan baik, hal ini terjadi karena Kelompok tani tersebut merupakan binaan sehingga sudah paham. Tetapi, yang belum dijalankan adalah penggunaan pupuk kandang atau pupuk organik, dengan alasan banyak pekerjaannya. Di samping itu, petani belum memahami fungsi dari pupuk organik tersebut. Hasil lain adalah cara pemupukan jagung manis yang dilakukan hanya sekali yaitu pada umur 15-30 hari setelah tanam, dengan jumlah pupuk phonska sekitar 5 gram. Dari diskusi dicoba untuk diterangkan mengenai dua hal tersebut disertai dengan contoh sampai petani mengerti dan faham keuntungan melakukan hal tersebut.

\section{Pembuatan Demplot}

Tujuan dari kegiatan ini adalah untuk meningkatkan pengetahuan dan pemahaman dan keterampilan kelompok masyarakat sasaran terkait sistim tanam tumpangsari. Teknik bertanam tumpangsari jenis tanaman hortikultura yang sesuai diharapkan dapat meningkatkan produktivitas lahan dan sekaligus meningkatkan pendapatan.

Pembuatan demplot diawali dengan pengolahan lahan pertanaman disini petani sudah mengetahui dan memahami fungsi pengolahan, dan Tim menerangkan apa yang terjadi bila lahan diolah kaitannya dengan pertumbuhan tanaman. Pembuatan demplot, permasalahan adalah dalam pembuatan bedengan karena mereka terbiasa dengan penggunaan mulsa untuk tanaman lain misanya tomat dan cabe, sehingga banyak ruang di bedengan yang tidak dimanfaatkan. Kegiatan ini dilakukan dalam rangka meningkatkan pengetahuan tentang pengelolaan lahan yang baik. Penanaman jagung dilakukan dengan jarak 20 x $70 \mathrm{~cm}$ dengan satu benih setiap lubang, sehingga 4 sachet benih diperoleh 6000 tanaman. Sedangkan selada yang ditanam berumur 3 minggu, dengan kriteria 4 daun.

Pendampingan pemeliharaan tanaman tumpangsari dalam mewujudkan kualitas hasil dengan menerapkan prinsip "GROWSAFE" artinya masih dibolehkan menggunakan pestisida dengan mempertimbangkan waktu residu, dan keadaan tanaman. Serangan hama belalang menjadi hal yang penting yang harus diperhatikan apalagi saat itu jarang ada tanaman jagung di sekitarnya. Pemupukan tanaman jagung manis dilakukan 2 kali yaitu umur 15 dan 35 hari, dengan masing-masing 5 gram, sedangkan selada hanya satu kali yaitu umur 15, kurang lebih 3 gram. 
Kendala yang terjadi adalah air irigasi yang terbatas, sehingga harus disiasati dengan terpal penampung air agar tanaman cukup dapat air.

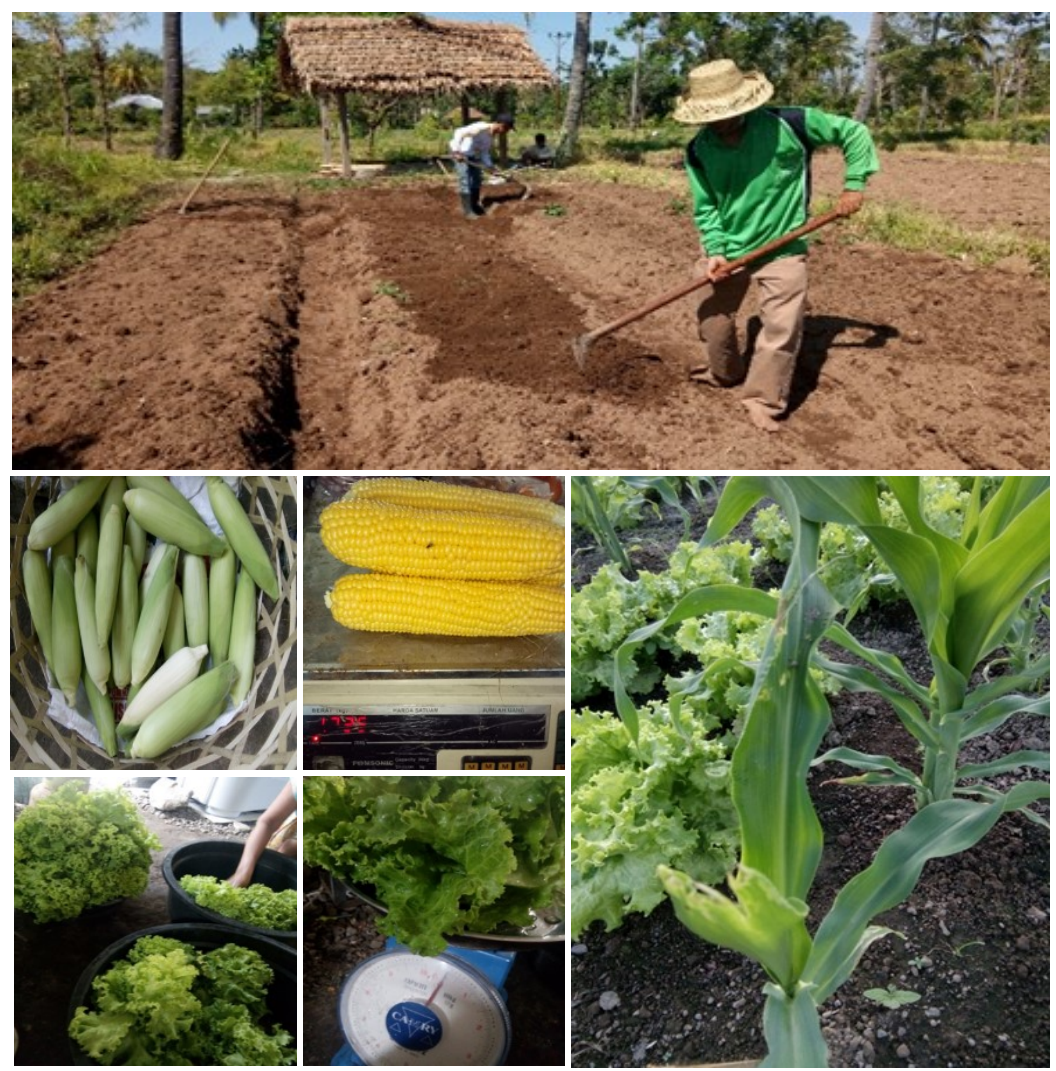

Gambar pembuatan demplot kegiatan penyuluhan (atas) dan keragaman panenan tanaman selada dan jagung manis hasil sistem tanam tumpangsari (bawah)

Hasil pengamatan di areal demplot yang dilakukan memberikan pengaruh yang cukup baik pada pertumbuhan jagung manis maupu selada. Hal ini dapat dilihat dari jumlah tongkol yang rata rata 2-3 tongkol per tanaman, bahkan ada yang 4 tongkol. Namun demikian tanaman jagung memiliki 4 tongkol biasanya tongkol yang keempat kurang baik. Sedangkan berat selada sudah mencapai rata-rata 180 gram/tanaman. Kualitas hasil jagung manis dan selada sudah mencapai kriteria untuk pasar moderen seperti hotel dan supermarket. Pada kesempatan tersebut petani juga mengakui bahwa terdapat perubahan pertumbuhan ke arah yang lebih baik dengan penggunaan pupuk kandang dibandingkan dengan tanpa penambahan pupuk organic (pupuk kendang).

Diskusi penguatan pengetahuan petani tentang masalah dalam tumpangsari, kualitas dan target pasar, tidak hanya dilakukan oleh tim, tetpi juga melibatkan PPL setempat, aparat Desa. Pertanyaan banyak dikemukakan oleh petani terutama masalah kebutuhan hotel, mengenai jenis dan harga yang ditawarkan. Selain itu bagaimana cara untuk memproduksi secara terus menerus untuk mensuplai kebutuhan hotel tersebut.

Penguatan memang sangat diperlukan dengan tidak mengabaikan pendampingan dan pemberian contoh sukses suatu Teknik bertanam yang lebih efisien. Jayaputra dkk. (2019) menguaraikan bahwa keterbatasan modal awal dan masalah pemasaran hasil dalam berusahatani seringkali menjadi alasan utama masyarakat miskin (petani) apalagi di Kawasan lahan kering tidak memanfaatkan lahan yang dimiliki secara optimal dengan menanam komoditas hortikultura yang memiliki nilai ekonomi tinggi karena membutuhkan biaya usahatani yang lebih tinggi. Mereka cenderung memilih tanaman yang sudah biasa mereka tanam (jagung, kacang tanah, dan beberapa komoditas hortikultura) dengan pertimbangan biaya produksi terjangkau, teknik pengelolaannya sudah terpola secara turun temurun (masih tradisional, minim inovasi teknologi budidaya), dan mudah dipasarkan. 


\section{Keragaan Tanaman}

Dari hasil pengamatan di lapangan, maka penanaman bersamaan antara jagung manis dan selada memperlihatkan hasil yang cukup baik dari segi kualitas dan kuantitas, sehingga disarankan melakukan tumpangsari dengan waktu tanam yang bersamaan antara jagung manis dan selada. Di samping itu nilai kesetaraan lahan adalah 1,62 artinya dari segi produktivas lebih menguntungkan tumpangsari 0,62 dibandingkan dengan monokultur.

Secara umum, kegiatan pengabdian kepada masyarakat yang telah dilakukan tim peneliti/penyuluh ini menunjukkan bahwa di Kawasan Hortikultura di Kabupaten Lombok Utara, khususnya di Kecamatan Kayangan Desa Kekait, Kelompok Tani Tangkok Kliang, metode penanaman sistem tumpangsari merupakan cara yang tepat dan cukup efektif dalam memanfaatkan lahan secara intensif dan efektif. Tumpangsari dengan penanaman yang bersamaan antara jagung manis dan selada dapat digunakan sebagai pedoman untuk mengembangkan pola bisnis di lahan hortikultura di Kawasan ini. Demikian halnya dengan hasil demplot tim penyuluh Hemon dkk (2020) bahwa terjadi peningkatan hasil kacang tanah yang ditumpangsarikan dengan okra. Demikian pula halnya dengan efisiensi penggunaan lahan terjadi peningkatan.

Jadi, salah satu alternatif pengembangan usaha tani di lahan sempit adalah dengan teknologi tumpangsari. Tumpangsari merupakan suatu usaha menanam beberapa jenis tanaman pada lahan dan waktu yang sama, yang diatur sedemikian rupa dalam barisan-barisan tanaman. Hasil demplot tumpang sari selada-jagung manis pada kegiatan penyuluhan ini menunjukkan bahwa dengan melakukan atau menerapkan pemupukan organik (pupuk kendang), efisiensi penggunaan air dan pengelolaan budidaya secara baik dan benar sesuai dengan kondisi agroklimat lahan kering setempat serta pendampingan yang intensif, produktivitas tanaman yang ditanam (pada areal demplot) mampu memberikan hasil yang diharapkan, yaitu telah mencapai standar kualitas pasar modern. Melalui melihat kenyataan dan mengamati pertumbuhan dan perkembangan tanaman selada dan jagung manis serta perolehan hasil yang memuaskan tersebut, para petani sasaran binaan menjadi sangat tertarik untuk pengembangan lebih lanjut namun mereka masih sangat mengharapkan pendampingan lebih lanjut.

\section{KESIMPULAN DAN SARAN}

Pola pikir petani hortikultura akan berubah dengan dilaksanakannya penyuluhan dan pendampingan yang terus menerus dengan disertai demplot penyuluhan seperti yang telah dilakukan di Kelompok Tani Tangkok Kliang. Perubahan pola pikir tidak hanya dalam pengelolaan lahan saja tetapi bagaimana merubah menjadi bisnis yang mendatangkan keuntungan. Hasil Penyuluhan menunjukan bahwa petani hortikultura sangat antusias terhadap inovasi dan teknologi tumpangsari yang dapat meningkatkan produktivas dan sekaligus pendapatan.

\section{Daftar Pustaka}

Hemon, A. F., Sumarjan, S., Listiana, B. E. 2020. Optimalisasi Produktivitas Lahan Sempit di Desa Sigerongan Lingsar Lombok Barat melalui Penerapan Tumpangsari Sayuran Okra dan Beberapa Genotipe Kacang Tanah. Jurnal SIAR ILMUWAN TANI. 1(1): 1-7. https://doi.org/10.29303/jsit.v1i1.2.

Herlina, N., M. Nawawi, T. Utami. 2014. Respon pertumbuhan dan hasil tanaman jagung (Zea mays L.) pada berbagai waktu tanam pakchoy (Brassica chinensis L.) dalam sistem tumpangsari. Prosiding Seminar Nasional PERHORTI, Malang. Hal: 218-225.

IFSCA (Innovative Farm Systems and Capability for Agribussiness Activity). 2020. Final Report of Horticultural Production in North Lombok District.

Jayaputra, I.G.M.A. Parwata, B.B. Santoso, I K. D. Jaya. 2019. Pengembangan Hortikultura Lahan Kering Berbasis Pertanian Organik Dengan Perbaikan Teknologi Budidaya Di Desa Kayangan Lombok Utara. Jurnal Gema Ngabdi. 1(3): 122-133. DOI: https://doi.org/10.29303/jgn.v1i3.54.

Nawawi. 2013. Pengaruh Saat Tanam Jagung Dalam Tumpangsari Tanaman Jagung (Zea mays L.) Dan Brokoli (Brassica oleracea L. var. botrytis). Jurnal Produksi Tanaman. 1 (3): 89. 
Nurrachman, 2015. Laporan Pendampingan Petani Hortikultura Kabupaten Lombok Utara. Kerjasama dengan BAPPEDA Kab. Lombok Utara.

Nurrachman, Suheri, H., Kusmarwiyah, R. 2019a. Pengembangan Brokoli Di Dataran Menengah Tumpangsari Dengan Jagung Manis (Seminar PEPADU II, Mataram).

Nurrachman, Jayaputra, Fauzi, Taufik. 2019b. Penerapan Teknologi Budidaya Untuk Meningkatkan Produktivitas Lahan dan Kesinambungan Suplai Produk Hortikultura (Seminar PEPADU II, Mataram). 
